\section{HARMONI SOSIAL}

Jurnal Pendidikan IPS
Harmoni Sosial: Jurnal Pendidikan IPS

Volume 3, No 2, September 2016 (112-124)

Online: http://journal.uny.ac.id/index.php/hsjpi

\title{
EFEKTIVITAS MODEL CTL DAN MODEL PBL TERHADAP HASIL BELAJAR IPS
}

\author{
Ari Wijayanti ${ }^{1}$, Taat Wulandari² \\ ${ }^{1}$ PPS Universitas Negeri Yogyakarta² Universitas Negeri Yogyakarta \\ wijayanti_reyrey@yahoo.com, taatwoelandari@yahoo.co.id
}

\begin{abstract}
Abstrak
Penelitian ini mengetahui perbedaan hasil belajar siswa yang menggunakan model PBL dan model CTL; serta membedakan efektivitas antara model CTL dan model PBL untuk meningkatkan hasil belajar IPS di SMPN 2 Bantul. Jenis penelitian adalah quasi experiment dengan subject match design. Populasi penelitian seluruh siswa kelas VIII SMPN 2 Bantul yang berjumlah 6 kelas. Sampel dipilih sebanyak dua kelas menggunakan teknik simple random sampling. Kelas VIII B sebagai kelompok eksperimen 1 (CTL), dan kelas VIII C sebagai kelompok eksperimen 2 (PBL). Teknik pengumpulan data menggunakan tes. Teknik analisis data menggunakan independent sample t-test, dilanjutkan dengan effect size. Hasil penelitian terdapat perbedaan peningkatan hasil belajar yang signifikan antara siswa yang belajar dengan model PBL dan model CTL. Model PBL lebih efektif daripada model CTL untuk meningkatkan hasil belajar IPS. Dapat dilihat dari effect size model PBL sebesar 3,02 lebih tinggi daripada effect size model CTL sebesar 2,02.
\end{abstract}

Kata Kunci: Contextual Teaching and Learning, Problem-Based Learning, Hasil belajar.

\section{THE EFFECTIVENESS OF THE CTL MODEL AND PBL MODEL ON THE LEARNING ACHIEVEMENT IN THE SOCIAL STUDIES}

\author{
Ari Wijayanti ${ }^{1}$, Taat Wulandari ${ }^{2}$ \\ ${ }^{1}$ PPS Universitas Negeri Yogyakarta² Universitas Negeri Yogyakarta \\ wijayanti_reyrey@yahoo.com, taatwoelandari@yahoo.co.id
}

\begin{abstract}
This study aims to know the significant difference of the learning achievement improvement between students who are taught by using the PBL model and that of those taught by using the CTL model, and the effectiveness between CTL and PBL models on the learning achievement in the Social Studies of the students of SMPN 2 Bantul. This research is a quasi experiment with the match subject design. The population is all of $8^{\text {th }}$ grade students of SMPN 2 Bantul. The sample was selected from two classes by using the random sampling technique. The first group was class VIII B (CTL), and the second group was class VIII C (PBL). The data collecting technique used was a test. The data analysis used the independent sample t-test, followed by the effect size.The result of this research shows that there is a significant difference of the learning achievement improvement between the students who were taught by using the PBL model and that of those taught by using the CTL model. It means the PBL model is more effective than the CTL model in improving the learning achievement in the Social Studies. It can be seen from the effect size of the PBL model 3.02 which is higher than that of the CTL model, that is 2.02.
\end{abstract}

Keywords: Contextual Teaching and Learning, Problem-Based Learning, Learning Result. 


\section{Pendahuluan}

Pendidikan mempunyai peranan yang penting dalam menentukan maju mundurnya suatu bangsa, karena melalui pendidikan diharapkan mampu melahirkan manusia-manusia yang cerdas dan berkompeten untuk memajukan bangsa tersebut. Untuk dapat mewujudkan pendidikan yang mampu melahirkan manusiamanusia cerdas dan berkompeten dalam upaya memajukan bangsa ini, diperlukan pendidik dalam hal ini adalah guru yang profesional, handal, dan kompeten di bidangnya.

Kegiatan pembelajaran merupakan aktivitas paling penting dalam keseluruhan upaya peningkatan mutu pendidikan. Hal ini disebabkan melalui kegiatan pembelajaran yang baiklah tujuan pendidikan akan tercapai, yaitu dalam bentuk perubahan perilaku pada siswa. Kegiatan pembelajaran di kelas adalah inti penyelenggaraan pendidikan yang ditandai oleh adanya kegiatan pengelolaan kelas, penggunaan media, sumber belajar, penggunaan metode dan model pembelajaran. Proses pembelajaran tidak hanya berpusat pada guru, tetapi harus mampu memunculkan keterlibatan siswa.

Hasil belajar siswa menjadi salah satu indikator keberhasilan dalam proses pembelajaran. Hasil belajar yang tinggi merupakan gambaran kemampuan siswa dalam menguasai materi yang telah disampaikan oleh guru. Hasil belajar juga merupakan indikator keberhasilan seorang guru dalam melaksanakan pembelajaran. Untuk meningkatkan hasil belajar IPS maka diperlukan suatu model pembelajaran yang mengutamakan keterlibatan siswa secara langsung. Jadi, pembelajaran terpusat pada siswa dan guru berperan sebagai fasilitator.

Hasil belajar dapat diketahui melalui assesment di mana hasil pengukuran tersebut menunjukkan sampai sejauh mana bahan ajar yang diberikan guru dapat dikuasai siswa. Hasil belajar merupakan sesuatu yang diperoleh, dikuasai atau dimiliki siswa setelah proses pembelajaran berlangsung. Seorang siswa dapat dikatakan telah mencapai hasil belajar jika pada dirinya telah terjadi perubahan tertentu melalui kegiatan belajar. Proses belajar efektif akan menjadikan hasil belajar lebih berarti dan bermakna.

Berdasarkan observasi di SMPN 2 Bantul, pada saat kegiatan pembelajaran IPS berlangsung terlihat bahwa sebagian besar siswa belum aktif dalam pembelajaran. Hal ini terlihat dari partisipasi siswa selama proses pembelajaran yang mayoritas masih rendah. Sebagai contoh ketika guru mengajukan pertanyaan, hanya ada satu atau dua siswa yang berani menjawab. Bahkan ketika guru meminta siswa mengajukan pertanyaan tidak ada siswa yang berani bertanya. Memang ada sebagian siswa yang benar-benar memperhatikan dan mengikuti pembelajaran dengan baik sampai berakhir, tetapi masih banyak pula yang kurang serius bahkan tidak memperhatikan penjelasan guru. Hal ini disebabkan oleh model, metode, pendekatan, dan strategi pembelajaran yang digunakan oleh guru kurang bisa memfasilitasi keberagaman gaya belajar siswa. Pendekatan yang masih sering digunakan guru adalah teacher centered. Kegiatan yang berlangsung hanya satu arah, yaitu penyampaian informasi dari guru ke siswa.

Metode pembelajaran yang digunakan oleh guru IPS di SMPN 2 Bantul belum bervariasi. Metode yang sering dipakai adalah metode konvensional yaitu ceramah, sehingga menyebabkan siswa menjadi cepat bosan selama kegiatan pembelajaran. Siswa kurang bersemangat untuk belajar IPS, apalagi jika pelajaran IPS pada jam terakhir. Hal ini terbukti dengan kurang aktifnya siswa selama proses pembelajaran.

Hasil rata-rata ulangan harian belajar IPS siswa SMPN 2 Bantul pada tahun 2013/2014 masih di bawah Kriteria Ketuntasan Minimal (KKM). Dapat dilihat dari tabel di bawah ini.

Tabel 1. Nilai Rata-Rata Ulangan Harian

\begin{tabular}{llllll}
\hline Kelas & KKM & \multicolumn{5}{l}{ Nilai Rata-rata Ulangan harian } \\
\hline & & 1 & 2 & 3 & 4 \\
VIII B & 70 & 67,80 & 68,90 & 66,50 & 69,50 \\
VIII C & 70 & 68,50 & 68,70 & 69,40 & 69,70 \\
\hline
\end{tabular}

Dari Tabel 1. dapat dilihat bahwa ratarata ulangan harian masih di bawah KKM. Belum tercapainya KKM pada rata-rata kelas tersebut dapat disebabkan oleh beberapa faktor. Faktor tingkat kesukaran materi, faktor daya serap atau tingkat pemahaman siswa, sarana pendukung pembelajaran, dan tentu saja faktor bagaimana cara guru menyampaikan materi pembelajaran. Penelitian ini menitikberatkan terhadap efektivitas pembelajaran mata pelajaran 
IPS yang berkaitan dengan hasil belajar siswa. Peneliti akan meneliti model pembelajaran yang digunakan dalam kegiatan belajar mengajar.

Berdasarkan observasi yang dilakukan peneliti, guru IPS belum pernah melaksanakan pembelajaran dengan model PBL dan model CTL. Hal ini terlihat dalam pembelajaran yang belum menerapkan kedua model pembelajaran tersebut, sehingga kurang bervariasinya model pembelajaran yang digunakan oleh guru.

Siswa hanya menghafal konsep dan kurang mampu menggunakan konsep tersebut jika menemui masalah dalam kehidupan nyata yang berhubungan dengan konsep yang dimiliki. Sebagian besar siswa kurang mampu menghubungkan antara apa yang mereka pelajari dengan bagaimana pengetahuan tersebut akan dimanfaatkan pada kehidupan sehari-hari. Akibatnya siswa kurang mampu menentukan masalah dan merumuskannya pada kehidupan sehari-hari.

Kurangnya kualitas dalam pembelajaran IPS merupakan suatu permasalahan yang sangat mendesak dan penting untuk segera dicari jalan keluar sebagai upaya meningkatkan hasil belajar siswa. Salah satu alternatif untuk memecahkan masalah tersebut dapat digunakan dan dikembangkan dengan efektivitas model Contextual Teaching and Learning (CTL) dan model Problem Based Learning (PBL).

Penelitian efektivitas hasil belajar IPS di SMPN 2 Bantul ini menggunakan model CTL. Model CTL adalah model yang melibatkan siswa secara penuh dalam proses pembelajaran, sehingga siswa aktif dalam proses pembelajaran. Sanjaya (2011, p.255) menyatakan bahwa belajar dalam konteks model CTL bukan hanya sekedar mendengarkan dan mencatat, tetapi belajar adalah proses berpengalaman secara langsung. Melalui proses berpengalaman itu diharapkan perkembangan siswa terjadi secara utuh, yang tidak hanya berkembang dalam ranah pengetahuan saja, tetapi juga ranah sikap dan keterampilan. Belajar dengan model CTL dapat memberi pengalaman belajar pada siswa secara lebih mendalam.

Johnson (2009, p.25) menjelaskan model CTL sebagai berikut:

The CTL system is an educational process that aims to help students see meaning in the academic material they are studying by connecting academic subjects with the context of their daily lives, that is, with the context of their personal, social, and cultural circumstances. To achieve this aim, the system encompasses the following eight component: making meaningful connections, doing significant work, self-regulated learning, collaborating, critical and creative thinking, nurturing the individual, reaching high standards, using authentic assesment.

Trianto (2012, p.107) menyatakan siswa akan terdorong membuat hubungan antara pengetahuan yang dimiliki dengan penerapannya dalam kehidupan mereka sehari-hari, dengan melibatkan tujuh komponen utama pembelajaran kontekstual yaitu konstruktivisme, bertanya, inkuiri, masyarakat belajar, permodelan dan penilaian autentik.

Model pembelajaran lain adalah model Problem Based Learning (PBL), yang menekankan kepada proses penyelesaian masalah yang dihadapi secara ilmiah.

Hamruni (2012, p.104) menjelaskan model PBL dikembangkan untuk membantu siswa dalam mengembangkan kemampuan berpikir, memecahkan masalah, dan keterampilan intelektual. Model pembelajaran ini menyediakan kondisi untuk meningkatkan keterampilan berpikir kritis dan analitis serta memecahkan masalah kompleks dalam kehidupan nyata sehingga akan memunculkan budaya berpikir pada diri siswa.

Mergendoller, Maxwell, dan Bellisimo (2008, p.49) menyatakan bahwa:

$P B L$ is an appealing instructional strategy. Rather than reading or hearing about the facts and concepts that define an academic field of study, students solve realistic (albeit, simulated) problems that reflect the decisions and dilemmas people face every day.

Rusman (2011, p.229) menjelaskan bahwa model PBL merupakan inovasi dalam pembelajaran karena dalam model pembelajaran ini kemampuan berpikir siswa betul-betul dioptimalisasikan melalui proses kerja kelompok atau tim yang sistematis, sehingga siswa dapat memberdayakan, mengasah, menguji, dan mengembangkan kemampuan berpikirnya secara berkesinambungan. Pembelajaran IPS yang dilaksanakan dengan model CTL dan model 
PBL dapat menjadi pilihan guru untuk dapat melaksanakan pembelajaran secara lebih efektif.

Tujuan dari penelitian ini adalah mengetahui perbedaan hasil belajar antara siswa yang menggunakan model CTL dan yang menggunakan model PBL dan membedakan efektivitas model CTL dan model PBL untuk meningkatkan hasil belajar IPS di SMPN 2 Bantul.

Manfaat Teoretis yang diperoleh menjelaskan tentang efektivitas model CTL dan model PBL, hasil peneltian ini dapat dijadikan referensi dalam meningkatkan hasil belajar IPS dengan model pembelajaran yang efektif, penelitian ini memprediksi bahwa hasil belajar IPS di SMPN 2 Bantul akan meningkat setelah adanya model CTL dan model PBL, model pembelajaran ini dapat dijadikan bahan pertimbangan untuk menentukan model pembelajaran yang tepat, dan hasil penelitian ini digunakan sebagai bahan peneliti untuk mengendalikan proses peningkatan hasil belajar IPS di SMPN 2 Bantul meningkat secara signifikan.

\section{Manfaat praktis yang dapat diperoleh}

diharapkan sekolah mampu mengembangkan pembelajaran dengan menggunakan model CTL dan model PBL, sehingga siswa merasa senang dalam mengikuti kegiatan belajar mengajar dan diharapkan selanjutnya hasil belajar siswa secara umum semakin baik dengan adanya variasi proses pembelajaran ini, melalui penelitian ini, peneliti berharap dapat mengembangkan kemampuan mengajar yang dimiliki disesuaikan dengan karakteristik siswa dan lingkungan sekitar siswa sehingga pembelajaran yang dilakukan dapat lebih bermakna, variatif dan penuh dengan inovasi serta sesuai dengan tuntutan perkembangan zaman, dan diharapkan dapat memberikan suasana belajar yang baru, pengalaman belajar lebih dalam, dan tantangan-tantangan pembelajaran sehingga semangat belajar siswa dapat terpompa dan dampak positifnya dapat meningkatkan hasil belajar siswa.

\section{Metode Penelitian}

Penelitian ini merupakan penelitian kuantitatif dengan pendekatan eksperimen semu (quasi experimen). Desain yang digunakan dalam penelitian ini adalah Match Subject Design.
Penelitian ini dilaksanakan di SMPN 2 Bantul pada kelas VIII semester dua. Penelitian ini mulai dilaksanakan bulan Maret 2015 sampai dengan bulan April 2015.

Populasi dalam penelitian ini adalah seluruh siswa kelas VIII di SMPN 2 Bantul tahun pelajaran 2015/2016 yang terdiri dari enam kelas yang berjumlah 145 siswa.

Pengambilan sampel dalam penelitian ini menggunakan teknik simple random sampling atau sampel acak sederhana dengan teknik undian. Undian ini dilakukan untuk memilih dua kelas yang akan dijadikan sebagai kelas eksperimen, sehingga diperoleh dua kelas sebagai sampel yaitu kelas VIII B sebagai kelompok eksperimen 1 (Model CTL) dan kelas VIII C sebagai kelompok eksperimen 2 (Model PBL).

Pengumpulan data dalam penelitan ini dilakukan dengan tes karena yang diukur adalah hasil belajar siswa. Bentuk instrumen tes yang dipakai adalah tes objektif untuk mengukur kompetensi kognitif siswa. Instrumen tes dalam penelitian ini terdiri atas soal pretest dan posttest berbentuk pilihan ganda sebanyak 20 item, yang digunakan untuk mengukur kemampuan awal sebelum perlakuan dan setelah perlakuan.

Teknik analisis data melalui dua tahap, yaitu tahap deskripsi data dan tahap pengujian hipotesis. Langkah-langkah yang dilakukan pada tahap uji deskripsi data ini adalah membuat rangkuman distribusi data pretest dan posttest dengan menggunakan program SPSS 20.00 for window.

Pengujian hipotesis pada penelitian ini menggunakan Independet Sample t-Test. Independet Sample t-Test digunakan untuk menganalisis perbedaan efektivitas model CTL dan model PBL yang ditinjau dari hasil belajar IPS.

Analisis data mengenai peningkatan kemampuan hasil belajar siswa juga dihitung dengan menggunakan Gain Score. Gain Score atau disebut juga dengan peningkatan atau perbedaan skor merupakan nilai siklus setelah treatment dikurangi nilai siklus sebelum treatment. Hasil analisis data dengan Gain Score disajikan dalam bentuk presentase sehingga dapat menunjukkan 
pencapaian peningkatan dengan memperhatikan kemampuan awalnya. Persentase peningkatan dihitung dengan cara:

$$
\text { Gain Score }=\frac{\text { Skor akhir }- \text { skor awal }}{\text { skor tes awal }} \times 100 \%
$$

Selanjutnya untuk menilai efektivitas model pembelajaran dilakukan dengan perhitungan effect size (ES). Rumus yang digunakan adalah sebagai berikut (Warner, 2008: 202).

$$
\mathrm{d}=\frac{\mathrm{M} 2-\mathrm{M} 1}{\mathrm{SP}}
$$

Keterangan:

$$
\begin{aligned}
& \text { Es }=\text { Effect } \text { Size } \\
& \text { M1 }=\text { Mean pretest } \\
& \text { M2 }=\text { Mean postest } \\
& \mathrm{Sp}=\text { Standar deviasi posttest }
\end{aligned}
$$

Kriteria yang diusulkan oleh Cohen tentang besar kecilnya ukuran efek adalah sebagai berikut:

Es $\leq 0,2$ (rendah)

$0,2<$ Es $\leq 0,8$ (sedang)

Es $>0,8$ (tinggi)

\section{Hasil Penelitian dan Pembahasan}

Penelitian ini terdapat dua kelompok data yang perlu dideskripsikan sesuai rancangan penelitian eksperimen yang menggunakan dua kelas eksperimen, yaitu data hasil eksperimen model CTL dan data hasil eksperimen model PBL. Deskripsi data hasil belajar siswa dilakukan dua kali tes yaitu tes awal (pretest) atau sebelum proses pembelajaran dan tes akhir (posttest) atau

\begin{tabular}{|c|c|c|c|}
\hline \multicolumn{2}{|c|}{$\begin{array}{l}\text { Hasil Statistik } \\
\text { Deskriptif }\end{array}$} & CTL & PBL \\
\hline \multirow{2}{*}{$\mathrm{N}$} & Valid & 15 & 15 \\
\hline & Missing & 0 & 0 \\
\hline \multicolumn{2}{|c|}{ Median } & $60,00^{\mathrm{a}}$ & $61,25^{\mathrm{a}}$ \\
\hline \multicolumn{2}{|c|}{ Mode } & 60 & 65 \\
\hline \multicolumn{2}{|c|}{ Std. Deviation } & 8,140 & 6,991 \\
\hline \multicolumn{2}{|c|}{ Variance } & 66,259 & 48,868 \\
\hline \multicolumn{2}{|c|}{ Skewness } &,- 125 & ,261 \\
\hline \multicolumn{2}{|c|}{$\begin{array}{l}\text { Std. Error of } \\
\text { Skewness }\end{array}$} &, 472 &, 472 \\
\hline \multicolumn{2}{|c|}{ Kurtosis } &,- 554 &,- 505 \\
\hline \multicolumn{2}{|c|}{$\begin{array}{l}\text { Std. Error of } \\
\text { Kurtosis }\end{array}$} & ,918 & ,918 \\
\hline \multicolumn{2}{|c|}{ Range } & 30 & 25 \\
\hline \multicolumn{2}{|c|}{ Minimum } & 50 & 50 \\
\hline \multicolumn{2}{|c|}{ Maximum } & 70 & 75 \\
\hline \multicolumn{2}{|c|}{ Sum } & 910 & 910 \\
\hline
\end{tabular}
sesudah proses pembelajaran berakhir.

Tabel 2. Deskripsi Data Pretest Hasil Belajar Siswa

\begin{tabular}{|l|l|l|l|}
\hline \multicolumn{2}{|l|}{$\begin{array}{l}\text { Hasil Statistik } \\
\text { Deskriptif }\end{array}$} & CTL & PBL \\
\hline \multirow{2}{*}{$\mathrm{N}$} & Valid & 15 & 15 \\
\cline { 2 - 4 } & Missing & 0 & 0 \\
\hline Mean & 60,67 & 60,67 \\
\hline $\begin{array}{l}\text { Std. Error of } \\
\text { Mean }\end{array}$ & 1,662 & 1,427 \\
\hline Median & $60,00^{\mathrm{a}}$ & $61,25^{\mathrm{a}}$ \\
\hline
\end{tabular}

Tabel 2. Lanjutan

Data pada Tabel 2. menunjukkan bahwa nilai rerata pretest pada kelompok eksperimen 1 yaitu kelas yang akan mengikuti pembelajaran dengan model CTL adalah sebesar 60,67; median 6,00; mode 60; standar deviasi 8,140; skor tertinggi 70 dan skor terendah 50. Untuk lebih memperjelas penyebaran skor hasil belajar siswa yang menggunakan model CTL dapat disajikan dalam bentuk diagram sebagai berikut:

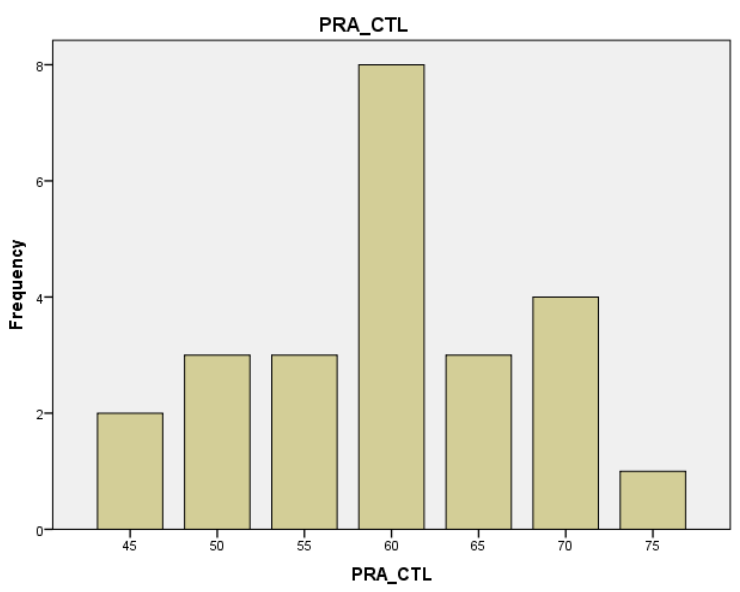

Gambar 1. Diagram Hasil Pretest kelas CTL

Data pada tabel juga menunjukkan bahwa nilai rerata pretest pada kelompok eksperimen 2 yaitu kelas yang akan mengikuti pembelajaran dengan model PBL adalah sebesar 60,67; median 61,25 ; mode 65; standar deviasi 6,991; skor 
tertinggi 75 dan skor terendah 50. Untuk lebih memperjelas penyebaran skor hasil belajar siswa yang menggunakan model PBL, dapat disajikan dalam bentuk diagram sebagai berikut:

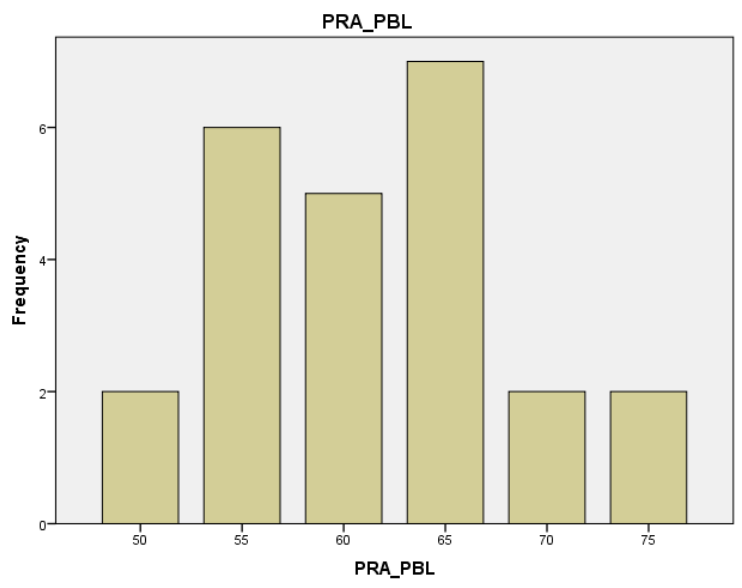

Gambar 2. Diagram Hasil Pretest kelas PBL

Tabel 3. Deskripsi Data Posttest Hasil Belajar Siswa

\begin{tabular}{|c|c|c|c|}
\hline \multicolumn{2}{|c|}{$\begin{array}{l}\text { Hasil Statistik } \\
\text { Deskriptif }\end{array}$} & \multirow{2}{*}{$\begin{array}{l}\text { CTL } \\
15 \\
\end{array}$} & \multirow{2}{*}{\begin{tabular}{|l|} 
PBL \\
15 \\
\end{tabular}} \\
\hline $\mathrm{N}$ & Valid & & \\
\hline IV & Missing & 0 & 0 \\
\hline \multicolumn{2}{|c|}{ Mean } & 80,33 & 84 \\
\hline \multicolumn{2}{|c|}{ Std. Error of Mean } & 1,829 & 1,561 \\
\hline \multicolumn{2}{|c|}{ Median } & $80.38 \mathrm{a}$ & $84,50 \mathrm{a}$ \\
\hline \multicolumn{2}{|c|}{ Mode } & 85 & $80 \mathrm{~b}$ \\
\hline \multicolumn{2}{|c|}{ Std. Deviation } & 8,958 & 7,649 \\
\hline \multicolumn{2}{|c|}{ Variance } & 80,254 & 58,514 \\
\hline \multicolumn{2}{|c|}{ Skewness } &,- 940 &,- 086 \\
\hline \multicolumn{2}{|c|}{$\begin{array}{l}\text { Std. Error of } \\
\text { Skewness }\end{array}$} & ,472 & ,472 \\
\hline \multicolumn{2}{|c|}{ Kurtosis } & ,195 & $-1,069$ \\
\hline \multicolumn{2}{|c|}{$\begin{array}{l}\text { Std. Error of } \\
\text { Kurtosis }\end{array}$} & ,918 & ,918 \\
\hline \multicolumn{2}{|c|}{ Range } & 35 & 25 \\
\hline \multicolumn{2}{|c|}{ Minimum } & 65 & 75 \\
\hline \multicolumn{2}{|c|}{ Maximum } & 90 & 95 \\
\hline \multicolumn{2}{|c|}{ Sum } & 1205 & 1260 \\
\hline
\end{tabular}

Data pada tabel menunjukkan bahwa nilai rerata posttest pada kelompok eksperimen 1 yaitu kelas yang akan mengikuti pembelajaran CTL adalah sebesar 80,33; median 80,38; mode 85; standar deviasi 8,958; nilai tertinggi 90; dan nilai terendah 65 . Untuk lebih memperjelas penyebaran skor hasil belajar siswa yang menggunakan model CTL dapat disajikan dalam bentuk diagram sebagai berikut.

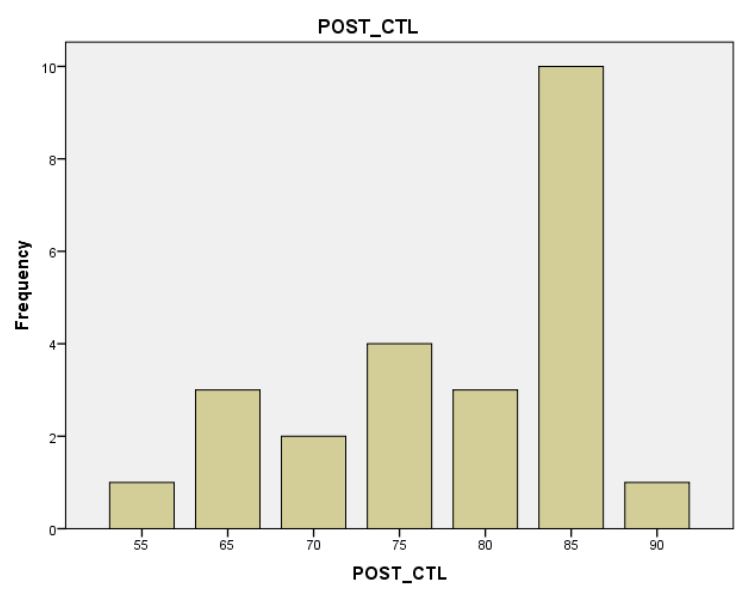

Gambar 3. Diagram Hasil Posttest kelas CTL

Data pada tabel 3. menunjukkan bahwa nilai rerata posttest pada kelompok eksperimen 2 yaitu kelas yang akan mengikuti pembelajaran PBL adalah sebesar 84 ; median 84,50 ; mode 80 ; nilai tertinggi 95 ; dan nilai terendah 75 . Untuk lebih memperjelas penyebaran skor hasil belajar siswa yang menggunakan model PBL, dapat disajikan dalam bentuk diagram sebagai berikut:

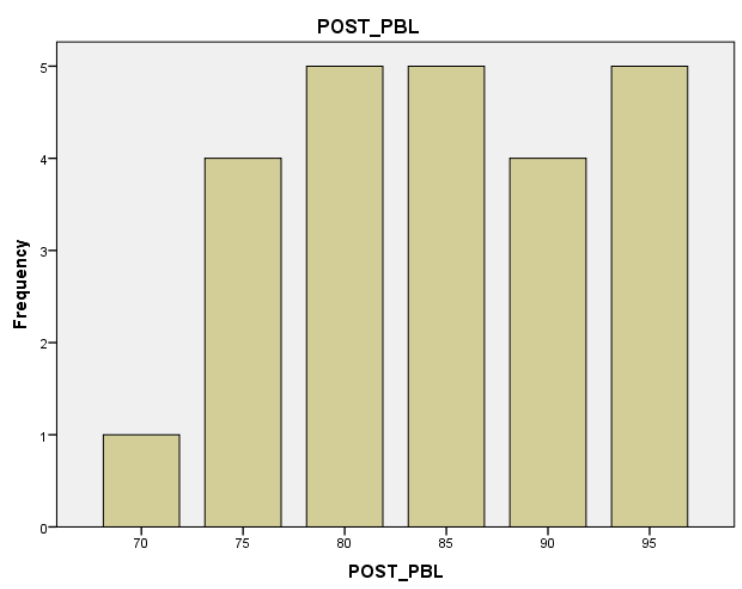

Gambar 4. Diagram Hasil Posttest kelas PBL

Peningkatan nilai hasil belajar kemudian dibandingkan perbedaannya antara kelas yang menggunakan model CTL dan model PBL. Masing-masing kelas terlebih dahulu dicari selisih antar nilai pretest dan posttest. Hasil perhitungan peningkatan skor hasil belajar IPS masing-masing kelas menunjukkan bahwa pada kelas CTL nilai rata-rata pretest sebesar 60,67 dan nilai rata-rata posttest sebesar 80,33; peningkatan 
rata-rata hasil belajar siswa mencapai 19,66. Sedangkan pada kelas PBL nilai rata-rata pretest sebesar 60,67 dan nilai rata-rata postest sebesar 84 peningkatan rata-rata hasil belajar siswa mencapai 23,33 .

Tabel 4. Perbandingan nilai Pretest, Posttest dan selisihnya (gain score)

\begin{tabular}{lcccc}
\hline \multicolumn{1}{c}{ Jenis Tes } & Kelas & N & Mean & $\begin{array}{c}\text { Standar } \\
\text { Deviasi }\end{array}$ \\
\hline $\begin{array}{l}\text { Pretest } \\
\text { hasil }\end{array}$ & CTL & 15 & 60,67 & 8,140 \\
Belajar & PBL & 15 & 60,67 & 6,991 \\
$\begin{array}{l}\text { Postest } \\
\text { hasil }\end{array}$ & CTL & 15 & 80,33 & 8,958 \\
$\begin{array}{l}\text { Belajar } \\
\text { Peningkatan }\end{array}$ & CTL & 15 & 84 & 7,649 \\
Hasil belajar & 15 & 19,66 & 0,818 \\
& PBL & 15 & 23,33 & 0,658 \\
\hline
\end{tabular}

Berdasarkan Tabel 4 dapat dilihat bahwa antara kelompok model CTL dan kelompok model PBL terdapat perbedaan hasil belajar yang signifikan. Kelompok model CTL dan kelompok model PBL memiliki hasil belajar yang berbeda, baik dari nilai pretest dan posttest.

Uji Hipotesis Pertama

Tabel 5. Uji Statistik Hasil Hasil Belajar Siswa Independent Sample t-Test

\begin{tabular}{|c|c|c|c|c|c|c|}
\hline & \multicolumn{6}{|c|}{ t-test for Equality of means } \\
\hline $\begin{array}{l}\text { Nilai } \\
\text { hasil } \\
\text { belajar }\end{array}$ & $\mathrm{F}$ & Sig & $\mathrm{T}$ & Df & $\begin{array}{c}\text { Sig. } \\
\text { (1-tailed) }\end{array}$ & $\begin{array}{l}\text { Mean } \\
\text { diffe- } \\
\text { rence }\end{array}$ \\
\hline siswa & 4,419 & 0,02 & 3,238 & 46 & 0,02 & 5,000 \\
\hline
\end{tabular}

Secara keseluruhan hasil perhitungan analisis variansi tentang perbedaan peningkatan hasil belajar siswa yang belajar dengan pembelajaran IPS model PBL dan model CTL dengan peluang kesalahan (p) sebesar 0,02 lebih kecil dari taraf signifikansi yang ditetapkan yaitu 0,05 . Hasil output SPSS pada tabel di atas dapat dilihat bahwa nilai t yaitu 3,238 dengan p-value lebih kecil dari alpha 0,05 maka $\mathrm{H} 0$ ditolak dan Ha diterima.

Berdasarkan hasil tersebut makam dapat disimpulkan bahwa hipotesis nihil (H0) ditolak, artinya "Terdapat perbedaan peningkatan hasil belajar yang signifikan antara siswa yang belajar dengan menggunakan model PBL dan yang menggunakan model CTL".

Untuk nilai Gain Score dari hasil perhitungan pada kelas CTL dan kelas PBL didapatkan persentase nilai pada tabel sebagai berikut.

Tabel 6. Persentase Gain Score

\begin{tabular}{lll}
\hline Kelompok & Tes & $\begin{array}{l}\mathrm{S} \mathrm{k} \mathrm{o} \mathrm{r} \\
\mathrm{H} \mathrm{a} \mathrm{s} \mathrm{i} 1 \\
\text { Belajar }\end{array}$ \\
\hline CTL & Rata-rata pretest & 60,67 \\
& Rata-rata postest & 80,33 \\
& Gain Score & 19,66 \\
PBL & \% Gain Score & 30,32 \\
& Rata-rata pretest & 60,67 \\
& Rata-rata postest & 84 \\
& Gain Score & 23,33 \\
& $\%$ Gain Score & 37,62 \\
\hline
\end{tabular}

Pada perhitungan dengan menggunakan Gain Score didapatkan persentase Gain Score hasil belajar pada kelas CTL sebesar 30,32 dan untuk kelas PBL sebesar 37,62. Data tersebut kemudian dapat dilihat bahwa pencapaian peningkatan hasil belajar siswa antara kelas CTL dan PBL terdapat perbedaan hasil belajar yang signifikan. Kedua kelas yaitu CTL dan PBL memiliki hasil belajar yang berbeda baik dari nilai pretest dan nilai postest, terutama pada peningkatan hasil belajar yang dilihat dari selisih antara nilai posttest dan nilai pretest (Gain Score) terdapat perbedaan peningkatan hasil belajar yang signifikan $(37,62>30,32)$.

Dari hasil penelitian, jelas bahwa model PBL secara kooperatif dapat meningkatkan hasil belajar IPS siswa hal ini karena model PBL merupakan pengajaran yang nyata dan sesuai dengan aktivitas siswa sehari-hari. Model PBL adalah proses pembelajaran yang titik awal pembelajaran berdasarkan masalah dalam kehidupan nyata lalu dari masalah ini siswa dirangsang untuk mempelajari masalah berdasarkan pengetahuan dan pengalaman yang telah mereka miliki sebelumnya sehingga dari sini akan dibentuk pengetahuan dan pengalaman baru. 
Uji Hipotesis Kedua

Tabel 7. Nilai Effect Size kelas CTL dan PBL

\begin{tabular}{lll}
\hline Kelompok & Tes & $\begin{array}{l}\text { Skor Hasil } \\
\text { Belajar }\end{array}$ \\
\hline \multirow{6}{*}{ CTL } & $\begin{array}{l}\text { Rata-rata } \\
\text { pretest }\end{array}$ & 60,67 \\
& $\begin{array}{l}\text { Rata-rata } \\
\text { postest }\end{array}$ & 80,33 \\
& Gain Score & 19,66 \\
& Standardeviasi & 8,140 \\
& Effect Size & 2,02 \\
PBL & Rata-rata & 60,67 \\
& pretest & \\
& Rata-rata \\
postest & 84 \\
& Gain Score & 23,33 \\
& Standardeviasi & 6,991 \\
Effect Size & 3,02 \\
\hline
\end{tabular}

Dapat disimpulkan bahwa "Penggunaan model PBL lebih efektif daripada model CTL terhadap hasil belajar IPS siswa SMPN 2 Bantul."

Perbedaan Peningkatan Hasil Belajar Antara Siswa yang Menggunakan Model CTL dan yang Menggunakan Model PBL

Berdasarkan hasil analisis menggunakan Independent Sample t-Test menunjukkan bahwa terdapat perbedaan yang signifikan antara hasil belajar IPS kelas yang diajar dengan model CTL dan kelas yang diajar dengan model PBL. Hasil dari penelitian ini menunjukkan bahwa pembelajaran IPS dengan model PBL lebih efektif dari model CTL.

Data dari hasil belajarsiswa, menunjukkan bahwa hasil belajar siswa yang diajar dengan model PBL lebih tinggi dibandingkan dengan hasil belajar siswa yang diajar dengan model CTL. Hal ini ditunjukkan dengan $p=0,02$ lebih kecil dari taraf signifikansi yang ditetapkan yaitu 0,05 , yang berarti signifikan. Hal ini juga terbukti bahwa hasil belajar siswa yang diajar dengan menggunakan model PBL memiliki peningkatan rata-rata hasil belajar mencapai 23,33; yang ternyata lebih tinggi dibandingkan dengan hasil belajar siswa yang diajar dengan menggunakan model CTL, yang peningkatan rata-rata hasil belajarnya mencapai 19,66.
Secara teoritis pembelajaran IPS dengan model PBL yang menggunakan masalah pada awal kegiatan pembelajaran memotivasi siswa untuk menyelesaikan masalah yang menarik dan juga menantang. Hal ini akan mempermudah siswa untuk berpikir pada taraf yang lebih tinggi dan terbiasa untuk menyelesaikan masalah. Pembelajaran IPS dengan model PBL yang difokuskan pada penggunaan masalah dapat membantu siswa untuk mengaitkan masalah yang ditemui dalam kehidupan sehari-hari sehingga siswa dapat memaknai materi pembelajaran yang akan disampaikan. Melalui penyelesaian masalah yang diberikan pada awal pembelajaran memberikan pengamalan belajar bagi siswa untuk memahami materi baru. Proses masalah yang tidak menekankan prosedur dan alogaritma membantu siswa untuk berpikir secara mandiri dalam menyusun rencana dan menyelesaikan masalah, mengevaluasi hasil penyelesaian dan menyiapkan alternatif pemecahan yang lain.

Model PBL dirancang masalah-masalah yang menuntut siswa mendapatkan pengetahuan yang penting, membuat mereka mahir dalam memecahkan masalah, dan memiliki strategi belajar sendiri serta kecakapan berpartisipasi dalam tim. Proses pembelajarannya menggunakan pendekatan yang sistemik untuk memecahkan masalah atau tantangan yang dibutuhkan dalam kehidupan sehari-hari.

Menurut Sanjaya (2011, p.214) terdapat tiga ciri utama dari model PBL. Pertama, model PBL merupakan rangkaian aktivitas pembelajaran, artinya dalam implementasi model PBL ada sejumlah kegiatan yang harus dilakukan siswa. Model PBL tidak mengharapkan siswa hanya sekedar mendengarkan, mencatat, kemudian menghafal materi, akan tetapi melalui model pembelajaran ini siswa aktif berpikir, berkomunikasi, mencari dan mengolah data, dan akhirnya menyimpulkan. Kedua, aktivitas pembelajaran diarahkan untuk menyelesaikan masalah. Model PBL menempatkan masalah sebagai kata kunci dari proses pembelajaran. artinya tanpa masalah maka tidak mungkin ada proses pembelajaran. Ketiga, pemecahan masalah dilakukan dengan menggunakan pendekatan berpikir secara ilmiah. Berpikir dengan menggunakan metode ilmiah adalah proses berpikir deduktif dan induktif. Proses berpikir ini dilakukan secara sistematis dan empiris. 
Sistematis artinya berpikir ilmiah dilakukan melalui tahapan-tahapan tertentu, sedangkan empiris artinya proses penyelesaian masalah didasarkan pada data dan fakta yang jelas.

Kelebihan pembelajaran dengan model PBL adalah dapat mendorong siswa untuk bekerja sama dalam kelompok. Di dalam kerja kelompok siswa yang lemah dalam pemahaman dapat terbantu oleh teman sebayanya dalam memahami konsep materi pembelajaran. Di dalam kelompok tersebut siswa mencoba untuk memecahkan permasalahan bersama yang akan mendorong pola pikir kreatif anak dalam memecahkan masalah yang terjadi di lingkungan sekitar mereka. Dalam proses penyelesaian masalah, siswa dapat berinteraksi dan berdiskusi bersama teman sekelompoknya.

Pada model PBL bersifat student centered. Guru memberikan tugas menggunakan wacana yang disajikan dalam LKS yang didalamnya terdapat masalah yang masih mengambang, kemudian siswa mencari solusi untuk memecahkan masalah yang diberikan. Siswa kemudian merumuskan masalah tersebut dan mencari pemecahannya. Dalam pemecahan masalah dilakukan dengan diskusi kelompok sehingga siswa dapat saling bertukar pikiran. Setelah permasalahan dapat dipecahkan, kemudian dilanjutkan dengan presentasi kelas. Pada presentasi ini akan terjadi diskusi dan pertukaran informasi kembali antar kelompok dalam satu kelas. Dari diskusi itu akan didapatkan pengalaman dan wawasan baru dan kadang ditemukan juga permasalahan-permasalahan baru yang berkaitan untuk dipecahkan. Dalam pemecahan masalah ini siswa juga mencari pengetahuan sendiri karena peran guru hanya sebagai fasilitator bukan pentransfer pengetahuan.

Model PBL bercirikan penggunaan masalah kehidupan nyata sebagai suatu yang harus dipelajari siswa. Dengan model PBL diharapkan siswa mendapatkan lebih banyak kecakapan daripada pengetahuan yang dihafal. Mulai dari kecakapan memecahkan masalah, kecakapan berpikir kritis, kecakapan bekerja dalam kelompok, kecakapan interpersonal dan komunikasi, serta kecakapan pencarian dan pengolahan informasi.

Perbedaan antara kedua model pembelajaran ini menunjukkan bahwa baik model PBL dan model CTL menyajikan materi pelajaran dengan gaya yang berbeda, meskipun ada kesamaan yaitu adanya kelompok-kelompok belajar dalam kegiatan pembelajaran. Secara teoritis kedua model pembelajaran ini dapat diterapkan untuk meningkatkan hasil belajar IPS siswa. Hal ini menunjukkan bahwa model PBL lebih unggul dibandingkan dengan model CTL.

Efektivitas Antara Model CTL dan Model PBL untuk Meningkatkan Hasil Belajar IPS di SMPN 2 Bantul

Berdasarkan hasil analisis data, telah terbukti bahwa pembelajaran IPS dengan menggunakan model PBL lebih efektif dalam meningkatkan hasil belajar siswa. Hal ini ditunjukkan dengan hasil perhitungan effect size untuk model CTL sebesar 2,02. Dari hasil perhitungan ini dapat dikatakan bahwa 2,02 mempunyai efek yang tinggi. Hasil perhitungan effect size untuk model PBL sebesar 3,02. Dari hasil perhitungan ini dapat dikatakan bahwa 3,02 mempunyai efek yang tinggi.

Hal ini juga terbukti bahwa siswa yang belajar dengan menggunakan model PBL memiliki skor rata-rata posttest sebesar 84,58 yang ternyata lebih tinggi dibandingkan dengan hasil belajar siswa yang belajar dengan menggunakan model CTL, yaitu 77,92.

Menurut Sanjaya (2011, p.220) model PBL memiliki beberapa keunggulan yaitu: (1) Pemecahan masalah merupakan teknik yang cukup bagus untuk lebih memahami isi pelajaran, (2) Pemecahan masalah dapat menantang kemampuan siswa serta memberikan kepuasan untuk menemukan pengetahuan baru bagi siswa, (3) Pemecahan masalah dapat meningkatkan aktivitas pembelajaran siswa, (4) Pemecahan masalah dapat membantu siswa bagaimana mentransfer pengetahuan mereka untuk memahami masalah dalam kehidupan nyata, (5) Pemecahan masalah dapat membantu siswa untuk mengembangkan pengetahuan barunya dan bertanggung jawab dalam pembelajaran yang mereka lakukan. Di samping itu, pemecahan masalah juga dapat mendorong untuk melakukan evaluasi sendiri baik terhadap hasil maupun proses belajarnya, (6) Melalui pemecahan masalah bisa memperlihatkan kepada siswa bahwa setiap mata pelajaran pada dasarnya merupakan cara berpikir, dan sesuatu yang harus dimengerti oleh siswa, bukan hanya 
sekedar belajar dari guru atau dari buku-buku saja, (7) Pemecahan masalah dianggap lebih menyenangkan dan disukai siswa, (8) Pemecahan masalah dapat mengembangkan kemampuan siswa untuk berpikir kritis dan mengembangkan kemampuan mereka untuk menyesuaikan dengan pengetahuan baru, (9) Pemecahan masalah dapat memberikan kesempatan pada siswa untuk mengaplikasikan pengetahuan yang mereka miliki dalam dunia nyata, dan (10) Pemecahan masalah dapat mengembangkan minat siswa untuk secara terus menerus belajar sekalipun belajar pada pendidikan formal telah berakhir.

Pada model PBL terdapatsejumlah kegiatan yang harus dilakukan siswa, yang mengharapkan siswa tidak hanya sekedar mencatat, kemudian menghafal materi pelajaran, akan tetapi siswa dituntut aktif berpikir, berkomunikasi, mencari dan mengolah data, dan akhirnya menyimpulkan. Aktivitas pembelajaran diharapkan untuk menyelesaikan masalah. Pemecahan masalah dilakukan dengan menggunakan pendekatan berpikir secara ilmiah.

Dalam model PBL masalah yang disajikan bersifat terbuka, artinya jawaban dari masalah tersebut belum pasti. Setiap siswa, bahkan guru dapat mengembangkan jawaban. Dengan demikian, dapat memberikan kesempatan pada siswa untuk bereksplorasi mengumpulkan dan menganalisis data secara lebih luas untuk memecahkan masalah yang dihadapi. Siswa dapat berpikir dengan kritis, analitis, sistematis, dan logis untuk menemukan alternatif pemecahan masalah melalui eksplorasi data.

Efektivitas model PBL dapat dilihat dari keberhasilan siswa dalam menyelesaikan masalah yang diberikan. Dengan demikian diharapkan dapat mendorong siswa untuk memahami materi pelajaran yang berkaitan dengan masalah dalam kehidupan sehari-hari. Model PBL menuntut siswa untuk aktif dalam memecahkan masalah. Konsep pemecahan masalah pada model PBL dilakukan dengan cara diskusi kelompok. Model PBL lebih menekankan pada pertukaran pendapat dan berbagi pengalaman dalam pemecahan masalah. Siswa yang memiliki motivasi tinggi akan lebih tertarik untuk mengexplore pengetahuan dan berkeinginan untuk mengetahui suatu hal baru guna memecahkan masalah yang berhubungan dengan dunia nyata. Model PBL dapat meningkatkan kemampuan berpikir kreatif siswa dalam pembelajaran IPS yang mana dengan pembelajaran berdasarkan masalah yang nyata dalam kehidupan sehari-hari/kontektual dengan adanya pemecahan masalah yang akan mengasah kemampuan berpikir siswa. Siswa dituntut memecahkan masalah, menganalisis permasalahan yang ada dalam kehidupan seharihari. Proses pembelajaran akan lebih bermakna dengan siswa menemukan jawabannya sendiri.

Masalah yang diberikan kepada siswa dalam metode PBL merupakan masalah yang berkaitan dengan kehidupan sehari-hari. Pemberian masalah dalam konteks dunia nyata ini bertujuan agar siswa mampu membangun sendiri pengetahuan baru yang diterimanya. Hal ini sesuai dengan pendapat Trianto (2007, p.67) bahwa pembelajaran berdasarkan masalah menyajikan situasi masalah yang otentik dan bermakna kepada siswa sehingga dapat memberikan kemudahan kepada mereka untuk melakukan penyelidikan dan inkuiri. Melalui permasalahan yang diberikan, siswa akan berusaha menyelesaikan masalah tersebut berdasarkan pengetahuan yang telah mereka miliki sebelumnya sehingga siswa mampu menemukan keterkaitan antara materi terdahulu dengan materi baru yang sedang mereka pelajari.

Masalah yang dijadikan sebagai fokus pembelajaran dapat diselesaikan siswa melalui kerja kelompok sehingga dapat memberi pengalaman belajar yang beragam pada siswa seperti kerjasama dan interaksi dalam kelompok, disamping pengalaman belajar yang berhubungan dengan pemecahan masalah seperti membuat hipotesis, merancang percobaan, melakukan penyelidikan, mengumpulkan data, menginterpretasikan data, membuat kesimpulan, mempresentasikan, berdiskusi, dan membuat laporan.

Keadaan tersebut menunjukkan bahwa model PBL dapat memberikan pengalaman yang kaya kepada siswa. Dengan kata lain, penggunaan model PBL dapat meningkatkan pemahaman siswa tentang apa yang mereka pelajari sehingga diharapkan mereka dapat menerapkannya dalam kondisi nyata pada kehidupan sehari-hari.

Model PBL memiliki karakteristikkarakteristik sebagai berikut: (1) Belajar dimulai dengan suatu masalah, (2) Memastikan bahwa masalah yang diberikan berhubungan dengan dunia nyata siswa/mahasiswa, 
Mengorganisasikan pelajaran diseputar masalah, bukan diseputar disiplin ilmu, (4) Memberikan tanggung jawab yang besar kepada pebelajar dalam membentuk dan menjalankan secara langsung proses belajar mereka sendiri, (5) Menggunakan kelompok kecil, dan (6) Menuntut siswa untuk mendemontrasikan apa yang telah mereka pelajari dalam bentuk suatu produk atau kinerja.

Dari karakteristik model PBL, yang telah diterangkan di atas, yaitu dimulai oleh adanya masalah (dapat dimunculkan oleh siswa atau guru), kemudian siswa memperdalam pengetahuannya tentang apa yang mereka telah ketahui dan apa yang mereka perlu ketahui untuk memecahkan masalah tersebut. Siswa dapat memilih masalah yang dianggap menarik untuk dipecahkan sehingga mereka terdorong berperan aktif dalam belajar. Hal ini merangsang seseorang untuk mengadakan reaksi untuk mencapai tujuan dalam suasana kompetisi demi mencapai sesuatu. Sehingga diasumsikan bahwa model PBL ini mempunyai kontribusi yang positif dalam meningkatkan motivasi berprestasi.

Pembelajaran IPS dengan model pembelajaran PBL memberikan pengaruh yang signifikan terhadap hasil belajar siswa dengan motivasi belajar rendah. Hal ini disebabkan siswa dengan motivasi belajar rendah lebih senang dengan langkah-langkah model pembelajaran PBL yang lebih sederhana dan singkat. Kegiatan pembelajaran dan penyelidiakan dalam pembelajaran PBL terjadi di dalam kelas serta tidak banyak melibatkan dunia luar, sehingga lebih mudah dan cocok untuk siswa yang memiliki motivasi belajar rendah (Madyarini, 2015, p.133).

Model PBL pembelajarannya lebih mengutamakan proses belajar, di mana tugas guru harus memfokuskan diri untuk membantu siswa, mencapai keterampilan mengarahkan diri. Guru dalam model ini berperan sebagai penyaji masalah, penanya, mengadakan dialog, membantu menemukan masalah, dan pemberi fasilitas pembelajaran. Selain itu, guru memberikan dukungan yang dapat meningkatkan pertumbuhan inkuiri dan intelektual siswa.

Model PBL merupakan model pembelajaran yang mendorong siswa untuk mengenal cara belajar dan bekerjasama dalam kelompok untuk mencari penyelesaian masalah-masalah di dunia nyata. Simulasi masalah digunakan untuk mengaktifkan keingintahuan siswa sebelum mulai mempelajari suatu subyek. Model PBL menyiapkan siswa untuk berpikir secara kritis dan analitis, serta mampu untuk mendapatkan dan menggunakan secara tepat sumber-sumber pembelajaran.

Dapat diartikan bahwa model PBL adalah proses pembelajaran yang titik awal pembelajaran berdasarkan masalah dalam kehidupan nyata lalu dari masalah ini siswa dirangsang untuk mempelajari masalah berdasarkan pengetahuan dan pengalaman yang telah mereka punyai sebelumnya sehingga akan terbentuk pengetahuan dan pengalaman baru. Diskusi dengan menggunakan kelompok kecil merupakan poin utama dalam penerapan model PBL. Model PBL merupakan satu proses pembelajaran di mana masalah merupakan pemandu utama ke arah pembelajaran tersebut. Dengan demikian, masalah yang ada digunakan sebagai sarana agar anak didik dapat belajar sesuatu yang dapat menyokong keilmuannya.

Model PBL bermaksud untuk memberikan ruang gerak berpikir yang bebas kepada siswa untuk mencari konsep dan menyelesaikan masalah yang terkait dengan materi yang disampaikan oleh guru. Karena pada dasarnya IPS bertujuan agar siswa memahami konsep-konsep IPS dengan kehidupan sehari-hari. Memiliki ketrampilan mengembangkan pengetahuan, mampu menerapkan berbagi konsep IPS untuk memecahkan masalah yang ditemukan pada kehidupan sehari-hari.

Melalui model PBL siswa tidak hanya sekedar menerima informasi dari guru saja, karena dalam hal ini guru sebagai motivator dan fasilitator yang mengarahkan siswa agar terlibat secara aktif dalam seluruh proses pembelajaran dengan diawali pada masalah yang berkaitan dengan konsep yang dipelajari. Karakteristik model PBL lebih mengacu pada aliran pendidikan kontruktivisme, dimana belajar merupakan proses aktif dari pembelajaran untuk membangun pengetahuan. Proses aktif yang dimaksud tidak hanya bersifat secara mental tetapi juga secara fisik. Artinya, melalui aktivitas secara fisik pengetahuan siswa secara aktif dibangun berdasarkan proses asimilasi pengalaman atau bahan yang dipelajari dengan pengetahuan yang telah dimiliki dan ini berlangsung secara mental. 
Selama proses pembelajaran guru harus dapat menciptakan lingkungan belajar sebagai suatu sistem sosial yang memiliki ciri proses demokrasi dan proses ilmiah. Pembelajaran berbasis masalah merupakan jawaban terhadap praktek pembelajaran kompetensi serta merespon perkembangan dinamika sosial masyarakat. Selain itu pembelajaran PBL pada dasarnya merupakan pengembangan lebih lanjut dari pembelajaran kelompok. Dengan demikian, model PBL memiliki karakteristik yang khas yaitu menggunakan masalah dunia nyata sebagai konteks belajar bagi siswa untuk belajar tentang berpikir kritis dan ketrampilan memecahkan masalah, serta untuk memperoleh pengetahuan dan konsep esensial dari materi pelajaran.

Model PBL digunakan untuk merangsang berpikir tingkat tinggi dengan situasi berorientasi pada masalah, termasuk didalamnya belajar bagaimanabelajar. Peran gurudalampembelajaran PBL adalah menyajikan masalah, mengajukan pertanyaan dan memfasilitasi penyelidikan dan dialog. Model PBL tidak dapat dilaksanakan tanpa guru mengembangkan lingkungan kelas yang memungkinkan terjadinya pertukaran ide secara terbuka secara garis besar pembelajaran PBL terdiri dari menyajikan kepada siswa situasi masalah yang autentik dan bermakna yang dapat memberikan kemudahan kepada mereka untuk melakukankan penyelidikan secara inkuiri.

Jadi, model PBL dan model CTL sama baiknya dalam meningkatkan hasil belajar siswa. Kedua model ini dapat meningkatkan hasil belajar IPS siswa. Model PBL mampu meningkatkan hasil belajar siswa dimana dari hasil perhitungan didapatkan data bahwa rata-rata peningkatan nilai kognitif sebesar 23,33.

\section{Simpulan, Implikasi, dan Saran}

Simpulan

Terdapat perbedaan peningkatan hasil belajar yang signifikan antara siswa yang belajar dengan menggunakan model CTL dan yang menggunakan model PBL. Hal ini dapat dilihat dari rata-rata peningkatan hasil belajar pada siswa yang belajar dengan model PBL mengalami peningkatan sebesar 23,12 di mana rata-rata pretest 61,46 meningkat menjadi 84,58 pada ratarata postest. Hasil ini lebih tinggi daripada ratarata peningkatan hasil belajar siswa yang belajar dengan model CTL sebesar 18,13 di mana ratarata pretest 59,79 meningkat menjadi 77,92 pada rata-rata posttest.

Model PBL lebih efektif daripada model CTL untuk meningkatkan hasil belajar IPS siswa di SMP Negeri 2 Bantul. Hal ini dapat dilihat dari perhitungan effect size model PBL sebesar 3,02 lebih tinggi daripada perhitungan effect size model CTL sebesar 2,02. Hasil ini menunjukkan bahwa pembelajaran baik dengan model PBL maupun model CTL efektif digunakan dalam pembelajaran IPS. Mengacu hasil tersebut, meskipun sama-sama memiliki efektivitas yang tinggi, namun model PBL terbukti lebih efektif dibandingkan dengan model CTL.

Implikasi

Hasil penelitian menunjukkan bahwa baik model PBL maupun model CTL dapat meningkatkan hasil belajar IPS siswa. Melihat hasil penelitian, jika guru menggunakan model PBL maka hasil belajar siswa akan mengalami peningkatan lebih tinggi dibandingkan apabila guru menggunakan model CTL. Untuk mendapatkan hasil belajar yang lebih baik, guru dapat menggunakan model PBL.

Saran

Beberapa saran untuk menggunakan model pembelajaran ini adalah: 1) dari hasil penelitian ini, model PBL lebih efektif daripada model CTL, maka sebaiknya guru menggunakan model PBL untuk meningkatkan hasil belajar IPS siswa; dan 2) model PBL adalah model pembelajaran yang menghadirkan masalah-masalah aktual dalam kehidupan yang erat dengan siswa, sehingga melalui pembelajaran yang menerapkan model ini, siswa sudah seharusnya mampu memaknai pembelajaran yang dilakukannya di sekolah sehingga mereka dapat tumbuh menjadi manusiamanusia pemberi jalan keluar terhadap masalahmasalah sosial khususnya yang ada di sekitarnya.

\section{DaftarPustaka}

Hamruni. (2012). Strategi pembelajaran. Yogyakarta: Insan Madani.

Johnson, E.B. (2009). Contextual teaching and learning. USA: A sage publications company. 
Madyarini, D.D. (2015). Komparasi model pembelajaran portofolio dan pbl terhadap hasil belajar ips di smpn kecamatan sewon. Harmoni Sosial Jurnal Pendidikan IPS, Volume 2, No 2.

Mergendoller, J.R., Maxwell, N.L. \& Bellisimo, Y. (2006). The effectiveness of problembased learning instruction: A comparative study of instructional methods and student characteristics. The Interdisciplinary Journal of Problem-based Learning, (1) 2, 49-69.
Rusman. (2011). Model-model pembelajaran. Jakarta: Raja Grafindo Persada.

Sanjaya, W.(2010).Kurikulum dan pembelajaran: teori dan praktik pengembangan kurikulum tingkat satuan pendidikan (KTSP). Jakarta: Kencana Prenada Media Group.

Trianto. (2012). Mendesain model pembelajaran inovatif-progresif. Jakarta: Kencana Prenada Media Group.

Warner, R.M. (2008). Appiled Statistic. USA: Sage Publications. 